\title{
Influence of Supervision Practices on the Teaching Practice Performance of Bachelor of Education Science Students: A Case of a Public University in Western Kenya
}

\author{
Rose Atieno Mutende \\ Kibabii University, Bungoma, Kenya
}

\begin{abstract}
This study analyses the influence supervision practices on the teaching practice performance of B.Ed Science students. The study was carried out in the Department of Science and Mathematics Education at Western University of Science Teacher Education. A total of 95 physics, chemistry and biology education students formed the study sample. Data obtained comprised of the B.Ed Science student views regarding the supervision practices, the supervisors comments on the University's Teaching Practice Assessment form and the assessment grades. When the data was analyzed, results showed a positive correlation between the supervision practices and the teaching practice performance of the B.Ed science students. Summative assessment grades were found to be lower than what the formative assessment comments suggested regarding the quality of the B.Ed Science student performance. These results raise the question of the validity of supervision and assessment as carried out by University lecturers. The results would be useful for the faculty involved in supervising and assessing B.Ed Science during teaching practice.
\end{abstract}

Keywords: Teaching Practice, Supervision, Formative Assessment, Summative Assessment

\section{INTRODUCTION}

One of the central issues underlying current debates about teacher preparation for quality education is what teacher need to know ${ }^{[1]}$ and the teaching practices that preservice teachers need to learn how to enact ${ }^{[2]}$. In this regard, teacher education programs the world over, provide for preservice teachers to be aided to put the theories and principles of education which they learnt in their university coursework into visible and tangible classroom performance ${ }^{[3]}$ and ${ }^{[4]}$. This is the practical aspect of teacher education widely known as 'teaching practice'. Teaching practice offers the preservice teachers an opportunity to demonstrate what they know and what they can do.

Teaching practice is school-based and done while under supervision in actual classroom settings. Supervision entails the preservice teacher being guided, advised, directed, and assessed, given feedback and then evaluated and scored against specified criteria. ${ }^{[5]}$ Notes that the supervision and assessment feedback is a key influencing factor on the preservice teacher's effectiveness of the practical application of teaching skills. ${ }^{[6]}$ Argues that the important teaching skills needed by a beginning teacher include lesson preparation, lesson presentations skills, and evaluation of learning. To effectively demonstrate science subjects teaching skills, student teachers need to learn to elicit their learners' ideas in order to adapt instruction, and press for evidence-based explanations of their views ${ }^{[7]}$. This means that while on teaching practice the student teacher must be supervised and assessed to ascertain that they are well grounded in lesson preparation and presentation techniques. The supervision and assessment out comes is an indication of the extent of their knowledge and teaching skills. Thus, if preservice teachers are not well supervised and assessed a lesson's instructional purposes may not be fully realized and this will lead to low quality of classroom instruction.

Western University of Science Teacher Education (WUSTE) offers Bachelor of Education (B.Ed) science. At WUSTE teaching practice is considered an integral part of preservice teacher training and the university envisions production of quality graduate teachers for science subjects. The B.Ed Science students are exposed to theoretical course work for the first three years and then 14 weeks of teaching practice at the end of third year. While on teaching practice, the B.Ed Science students are 
expected to apply the knowledge and skills of teaching acquired during coursework, practice the approaches, methods and techniques for teaching science, participate in the schools co-curricular activities as well as get to understand the school, organizational and administrative activities.

Teaching practice has been hailed for integrating classroom education with practical experience in enabling student teachers to develop their professional knowledge and professional skills. However, the challenge of incompetent graduate teachers particularly in science subjects persists ${ }^{[8]}$ and ${ }^{[9]}$. Although researchers agree that effective school-based supervision and assessment of preservice teachers is the crucial link between quality teaching and improved learner outcomes, there is limited literature on the direct influence of supervision and assessments on the teaching practice performance of B.Ed science students.

The purpose of the study is to investigate the influence of formative and summative assessment feedback on the teaching practice performance of B.Ed science students at WUSTE. The objectives of the study are; to examine the influence of supervision practices on the teaching practice performance of B.Ed science students at WUSTE, to analyze the influence of formative assessment on the teaching practice performance of B.Ed science students at WUSTE and to determine the influence of summative assessment on the teaching practice performance of B.Ed science students at WUSTE.

\section{LiterATURE REVIEW}

The need for supervision and assessment derives from the unpredictable relation between teaching and learning ${ }^{[10]}$. ${ }^{[11]}$ Argue that the main purpose of supervision and assessment during teaching practice is to establish whether classroom instructional practices have achieved the lesson objectives or not. ${ }^{[12]}$ points out that the role of the supervisor is to observe and assess lessons, advise, direct, guide, counsel and provide the feedback aimed at helping the student teacher identify their areas of growth and improvements to be made. The supervision and assessment determines the extent to which student teachers have acquired and can apply the knowledge, skills, and dispositions necessary to achieve the lesson objectives. ${ }^{[13]}$ Argues that both formative and summative assessments are necessary to assess the quality of teaching.

In an effort to improve the supervision and assessment of teaching practice the criteria used at WUSTE focus on teacher knowledge, skills and dispositions of the B,Ed Science students in the teaching and learning contexts. Guided by the criteria, the B.Ed Science students are supervised, assessed and scored on their teaching skills. The score is assigned based on how the student teacher performs during content delivery in the class. The grade awarded reflects the supervisee's performance at that time.

A study ${ }^{[14]}$ on supervision of teacher performance established that feedback was limited to the use of skills like chalkboard writing, introducing lessons, class discipline and media use and also emphasis on the progressive improvement of the teacher, the teaching methods adopted and stimulus variations whatever they were effectively used in class or not.

Another study on oral feedback, ${ }^{[15]}$ found that TP students had more conversations with cooperating teachers than the university supervisors.

The MET study revealed that scores by multiple observers may vary significantly because a supervisee may display different teaching skill from one lesson to another. Thus, an accurate picture of supervisee performance can be obtained from the mean scores across more than one lesson so as to ensure fairness and accuracy. The MET study also found out that as the number of assessors and lessons observed increased, the higher the reliability of the scores for any individual student teacher.

Formative assessment indicates the existence of a gap between the actual and the required levels of performance with suggestions on how to improve to reach the required level ${ }_{[13]}$. Useful feedback has a positive impact on the preservice teacher. According to ${ }^{[11]}$ first, it describes the current status so the student becomes aware of his/her strengths and weaknesses and secondly, it reduces the discrepancy between current knowledge and the learning goal thus ultimately improves teaching performance.

At WUSTE, teaching practice is considered a process of formative assessment during which the experienced supervisors assess the extent of learning of the B.Ed Science students from the coaching, modelling, guidance and direction that they provide. The supervisor's task is to provide clear 
feedback on the current level of performance and give constructive feedback that will move the B.Ed Science student to the next achievable goal.

In preservice teacher education, summative assessment summarizes a supervisee's accumulated knowledge and classroom practices over time. Effective assessment of the teaching practices, focus on what the preservice teachers do in the classroom is based on a clear set of performance tasks that are aligned to the lesson objectives. This makes assessment a powerful tool for determining a supervisee's teaching competence, and the support needed to effect changes in teaching skill development ${ }^{[3]}$. At WUSTE, the summative assessment scores awarded determines preservice teacher's level of performance. The score is arrived at by assessing teaching practice performance at specific times during the teaching practice session. By gathering, and interpreting data and giving judgment, the university supervisors provide evidence of the effectiveness of a supervisee's performance in light of the adopted performance criteria. The criteria used include preparation of professional documents, lesson introduction, presentation, and conclusion, their involvement in the school's co-curricular activities, ad teacher attire and personality. In addition, they also carry out the school environmental study and basic educational research in an area of their choice.

Teaching practice as a learning experience is based on the constructivist theory that learning takes place in contexts in which learners are facilitated to construct what they learn as a function of their experiences ${ }^{[16]}$. In this regard learning during teaching practice is possible in a learning environment that has access to supervisors who initiate the supervisees into the profession. The supervision practices reflect the general principles of social constructivism and metacognition.

\section{RESEARCH METHODOLOGY}

\subsection{Research Design}

This study employed a descriptive survey design. Closed-ended questionnaires were used to gather quantitative data while open-ended questionnaires were used to gather qualitative data. This allowed triangulation which ${ }^{[17]}$ point out ensures that the strengths of qualitative data offset the weaknesses of the quantitative data and vice versa.

\subsection{Target Population Sample Size and Sampling Procedure}

The target population for this study was the B.Ed Science students at WUSTE. The sample which qualified for multiple regression analysis comprised 95 B.Ed science students in the May - August 2016 teaching practice session.

\subsection{Research Instruments}

Questionnaire items related to supervision practices on the teaching practices of B.Ed science students were constructed. Each item in the questionnaires was based on a 5-point Likert Scale to obtain the respondents degree of agreement or disagreement. The WUSTE teaching practice and assessment form provided the checklist for the B.Ed Science students teaching practices, written comments made by the supervisors and scores obtained.

\subsection{Validity and Reliability}

Expert opinion of the questionnaire, and the pilot study done on $10 \%$ of the sample assessed the validity of the instrument and the content validity of the study variables. Construct validity was tested using Kaiser-Meyer-Olkin Measure and Bartlett's Test of Sphericity. Both results showed that the values met the threshold. Hence, the results of the constructs were valid. Reliability was measured using Cronbach's Alpha of coefficient test and at 0.70 exceeded the 0.6 lower level of acceptability [18].

\section{ReSults AND Discussions}

\subsection{Influence of Supervision Practices on Teaching Practice Performance}

The demographic profile solicited background information of the sample. The supervision practices were operationalized and the statements anchored on a five point Likert-type scale. Fifty-two pointone per cent $(52.1 \%)$ of the respondents suggested that their supervisors held meetings with them to ascertain that their teaching documents were appropriate, $75.7 \%$ suggested that the assessment 
feedback they got from the supervisors linked to their teaching practices, $63.9 \%$ suggested that the interaction with their respective supervisors during their visits was friendly, $83 \%$ suggested that they used the feedback to improve subsequent lessons, $73.0 \%$ suggested that their supervisors were always in time for lessons, and $72.5 \%$ suggested that their supervisors advised and guided them on the appropriate teaching practices. The respondents' aggregate score of supervision practices computed as the simple average of the mean scores of the respective sub- constructs responses produced a mean score of 4.407 (agree) indicating that supervision practices have a positive effect on teaching practice performance of the students on teaching practice. Results of multiple regression analyses done to establish the influence of supervision practices on teaching practice performance of the B.Ed science students showed that supervision practices had a statistically significant contribution in the prediction of the teaching practice performance $(t=10.153, p=0.01<0.05)$. Additionally, supervision practices had partial correlation coefficient of 0.416 and a positive standardized beta coefficient of 0.610 . Therefore, the null hypothesis was rejected and it was concluded that at 5\% significance, supervision practices has a significant influence on the teaching practice performance among B.Ed Science students such that improvement in the supervision practices leads to a rise in the teaching practice performance among the B.Ed science students.

These results show that the B.Ed Science students of WUSTE were given relevant and adequate support by their supervisors and that the B.Ed Science students perceived their supervisors as being effective in assessing their teaching practice. Therefore as noted by ${ }^{[19]}$ and ${ }^{[20]}$ teaching practice is a key component of pre-service teachers' education program and is highly valued by the B.Ed Science students ${ }^{[5]}$. The experience helps the preservice teachers to develop a contextualized understanding of the complex teaching and learning environment and provides an opportunity to develop teaching competencies. However as observed by ${ }^{[21]}$ for the supervisors to provide effective supervision they need to be well grounded in pedagogical and personal principles that underpin teachers' work.

\subsection{Influence of Formative Assessment on Teaching Practices}

Results on formative assessment showed that $72.2 \%$ suggested that the criteria used to assess them were related to classroom instructional practices, 56.9\% suggested that the feedback they received was linked to their teaching practices, $65.2 \%$ suggested that the assessment feedback motivated them to improve their practices, $69.1 \%$ suggested that they used the assessment feedback for subsequent teaching, 48.6\% suggested that the assessment feedback was prompt, 65.3\% suggested that the feedback assessment was based on clear explicit explanations of their performance against stated criteria and $55.1 \%$ suggested that the assessment feedback gave them clear indication of how to improve their performance, $46.2 \%$ suggested that the assessment feedback enabled them to develop a critical reflection of their own work. When the aggregate score was computed as the simple average of the respective sub- constructs scores, a mean score of 4.1728 (agree) was obtained showing that formative assessment has a positive effect on the B.Ed Science students' teaching practice performance. The study further revealed coefficients $t=9.115, p=0.003<0.05$ which indicate that formative assessment has a statistically significant unique contribution in the prediction of the teaching practice performance of B.Ed Science students. Results of the zero order correlation revealed a significantly strong positive correlation between formative assessment and teaching practice performance of B.Ed Science students $(R=0.587>0.5, p=0.001<0.05)$. Again, formative assessment had a part correlation coefficient of 0.414 and a positive standardized beta coefficient of 0.582 . This is enough evidence to conclude that at $5 \%$ significance level formative assessment has a positive influence on the teaching practice performance among the WUSTE B.Ed Science students. An improvement in the assessment leads to an improvement in the teaching practice performance among the B.Ed. Science students.

This results show that the assessment feedback was helpful to the B.Ed science students and helped them to improve their performance while on teaching practice. It is also evident that for assessment feedback to be beneficial it should indicate the existence of a 'gap' between the actual level of the work being assessed and the required standard as well as an indication of how the work can be improved to reach the required standard. According to ${ }^{[4]}$ such support for preservice teachers is an essential component of the teaching practice program. In the same vein ${ }^{[22]}$ stated that more frequent feedback from university supervisors is related to greater preservice teacher confidence and desire to be effective teachers. Thus, the feedback provided guidance, advice, direction and even modelling received from university supervisors play a critical role in the B.Ed Science students learning to teach. 
Influence of Supervision Practices on the Teaching Practice Performance of Bachelor of Education Science Students: A Case of a Public University in Western Kenya

\subsection{Influence of Summative Assessment on Teaching Practices}

Summative assessment was operationalized as per the components and criteria on the WUSTE teaching practice and assessment form. Majority of the respondents $72.2 \%$ suggested that the criteria used to assess them was related to their classroom instructional practices, 95\% agreed that their teaching documents were aligned, 53.8\% suggested that during lesson introduction they reviewed previous lessons and learner experiences, $52.3 \%$ had mastery of content and used appropriate teaching methods, $68.4 \%$ suggested they used appropriate teaching resources, $88.5 \%$ had classroom control, $84 \%$ summarized the lessons at the conclusion, 93\% suggested their appearance, communication and confidence was appropriate for teaching while $98 \%$ agreed that they participated in co-curricular activities. The results further showed that all the students attained a score above $40 \%$. However, only $41.6 \%$ had their scores aligned to the supervision comments while the rest had scores inconsistent with the supervision comments. Summative assessment was found to have a statistically significant unique contribution in the prediction of the teaching practice performance of B.Ed science students $(t=9.802, p=0.01<0.05)$. On analyzing the results of the zero order correlation a significantly strong positive correlation was found between summative assessment and teaching practice performance $(R=0.546>0.5, p=0.003<0.05)$ and a partial correlation of 0.298 was obtained. Summative assessment had a positive standardized beta coefficient of 0.531 in the coefficients results. Basing on the above results, it can be concluded that at 5\% significance level summative assessment have a significant positive influence such that increased frequency in application of summative assessment leads to an improvement in the teaching practice performance of the B.Ed science students at WUSTE.

The results show that summative assessment is a judgement that captures evidence of performance for a defined period, and focuses on learner outcome. In this study, the assessment criteria used focused on areas that require improvement and that meaningful accompanying comments were made to guide the B.Ed Science students in the desired directions. It was however found that in some cases the supervisors gave grades which did not reflect the comments they made about the teaching performance. The grades were lower compared to the positive comments made about students' performance. This phenomenon highlights a mismatch between formative and summative assessment contrary to the findings of a similar study by ${ }^{[21]}$, yet the comments which relate to performance should be used to judge the quality of teaching in accordance with the established criteria.

\subsection{Teaching Practice Performance among the B.Ed. Science Students}

Majority of the respondents, $93.1 \%$ strongly agreed that they planned for instructions as per the teaching objectives, $42.6 \%$ and $44.1 \%$ agreed/ strongly agreed (respectively) that they planned for instructions as per the level of students, $78.7 \%$ strongly agreed that they asked questions to gauge students' ideas of the topic/subtopic, $50.7 \%$ strongly agreed that they linked the content to students' life experiences and/or natural phenomenon, $61.3 \%$ strongly agreed that they held demonstrations ahead of laboratory practical, $75 \%$ strongly agreed that they provided feedback to students, $74.7 \%$ strongly agreed that they gave assignments at the end of every lesson, 53.3\% strongly agreed that they assessed students basing on the learning objectives and $78.7 \%$ strongly agreed that they evaluated own lessons. When the respondents' aggregate score of teaching practice performance among KIBU students was computed as a simple average, a mean score of 4.3721 (agree) was obtained. This showed that the teaching practice performance among WUSTE students is relatively high.

To determine the best predictor of teaching practice performance standardized beta coefficients was used. It was found that supervision practices had a standardized beta coefficient of 0.610 , formative assessment had a standardized beta coefficient of 0.582 and summative assessment had a standardized beta coefficient of 0.531 . This means that supervision provides the strongest unique contribution to explaining the teaching practice performance of B.Ed. science students. When the variance explained by formative and summative assessments is controlled for, formative assessment provided moderate contribution while summative assessment made the least contribution among the variables. Thus, at $5 \%$ level of significance, the supervision practices employed by WUSTE University supervisors is a predictor of teaching practice performance among the B.Ed science students. Specifically, formative assessment accounts for a higher level of teaching practice performance than summative assessment. However, these assessments have been found to measure teacher performance and help preservice teachers improve their teaching performance ${ }^{[23]}$. Unfortunately, the dual function of supervision and 
assessment appears to be challenging and university supervisors may fail to optimally support student teachers since they are overloaded. This finding justifies what [24] stated as the assessments of students' competence during practicum remain problematic and a number of issues remain continuous.

This study found that the dual function of university lecturers of being supervisors and assessors at the same time has the potential to give contradictory feedback to the students about their performance as observed in the inconsistency between assessment grades and supervision comments. Even though this could perhaps be because they were meant to capture the momentary student performance, the study recommends that the WUSTE University supervisors undergo a teaching practice supervision and assessment induction course focusing on assessment and evaluation process aligned to the criteria on the WUSTE University's teaching practice and assessment form.

The supervision and formative assessment feedback was the highest contributor to an improved teaching practice performance. Therefore the study recommends that the B.Ed Science students be supervised more frequently so as to offer guidance and advice on the teaching and learning process. This could easily be achieved if WUSTE University management considers partnering with the teaching practice schools to offer this support. Specifically, WUSTE University could offer an inservice training to the science subject heads in the teaching practice schools to provide the guidance including modelling of the needed teaching skills.

\section{Conclusion}

The study has provided evidence about how the supervision practices supports the teaching practice performance of preservice teachers that can be added to the existing body of literature related to the supervision. The study has revealed that the supervision and assessment of school-based teaching practice provides realistic experiences, and support the B.Ed Science students' need to overcome their preconceptions of teaching and sharpen their teaching skills. The B.Ed Science students have been found to highly value teaching practice and perceive their supervisors as being effective in assessing their teaching skills. This means supervision and assessment of teaching play a critical role in teacher learning. While formative assessment offers support for improving teaching skills, summative assessment has a gate keeping function of selecting suitable student teachers and thereby protects the profession from incompetence. Thus, an improvement of the supervision and assessment process as well as the frequency will improve the teaching practice performance of B.Ed Science students on teaching practice.

\section{REFERENCES}

[1] Darling-Hammond, L., and Bransford, J. (Eds.). (2005). preparing teachers for a changing world: What teachers should learn and be able to do. San Francisco: Jossey-Bass.

[2] Ball, D. L., \& Forzani, F. M. (2009). The work of teaching and the challenge for teacher education. Journal of Teacher Education, 60(5), 497-511.

[3] Darling-Hammond, L. (2008). Creating a comprehensive system for evaluating and supporting effective teaching. Retrieved from http://edpolicy.stanford.edu/publication/pubs/591

[4] Kaphesi, E. (2013). Assessing final year undergraduate student teacher on school based teaching practice at the Polytechnic of the University Malawi: a dual assessment process. African Journal of Teacher Education, 3(2). (2) 5-17

[5] Beck, C. and Kosnik, C. (2002). Components of a good practicum placement: Student teacher perceptions. Teacher Education Quarterly, 29(2), 81-98.

[6] Tanak A. (2013). The Development of Preservice Teachers' Teaching Practice Through Reflective Process. Official Conference Proceedings. The Asian Conference on Education 2013.

[7] Windschitl, M., Thompson, J., Braaten, M. and Stroupe, D. (2012). Proposing a Core Set of Instructional Practices and Tools for Teachers of Science, Science Education, 96(5), 878- 903

[8] Ministry of Education (2012). A Policy Framework for Education. Aligning Education and Training to the Constitution (2010) and Beyond. Nairobi.

[9] Ishihara N. (2012). Critical narratives for teaching pragmatics: Applications to Teacher Education. The European Journal of Applied linguistics and TEFL 
Influence of Supervision Practices on the Teaching Practice Performance of Bachelor of Education Science Students: A Case of a Public University in Western Kenya

[10] Wiliam, D (2010) the role of formative assessment in effective learning environments, in H.Dumont, D. Istance and F. Benavides (eds) The Nature of Learning: Using Research to Inspire Practice. Paris: OECD, 135-159

[11] Hattie, J. \& Timperley, H. (2007). The power of feedback. Review of Educational Research, $77(1), 81-112$.

[12] kbar, Z (2002). Economic and Political Weekly, Vol. 37, No. 35 (Aug. 31 - Sep. 6, 2002), pp. 3644-3661

[13] Taras, M. (2005). Assessment, Summative and Formative: Some Theoretical Reflections. British Journal of Educational Studies. Vol 53(4). Pgs 466 - 487

[14] Bhargava A. (2009). Teaching practice for student teachers of B.Ed programme: Issues, predicaments and suggestions. Turkish Online Journal of Distance Education, 10(2) 3.

[15] Hu C. and Wong F. (2012). Video conferencing by student teachers: Does it make any difference? New Horizons in Education, 53, 2006, 42-56.

[16] Schunk, D. (1996) Goals and self-evaluative influences during children's cognitive skill learning, American Educational Research Journal, 33(2), 359-382.

[17] Gray, L. G. E. Mills and P. Airasian (2009). Educational Research: Competencies for Analysis and Applications. New Jersey: Pearson.

[18] Hair, Jr., J.F., Black, W.C., Babin, B.J., Anderson, R.E., Tatham, R.L., (2006). Multivariate data analysis (6th Ed.), Pearson-Prentice Hall, Upper Saddle River, NJ.

[19] Grootenboer P. J (2006). The impact of school-based practicum on preservice teachers' affective development in mathematics. Mathematics Teacher Education. (7) 18-32

[20] Wilson, E. K. (2006). The impact of an alternative model of student teacher supervision: Views of the participants. Teaching and Teacher Education, 22, 22-31.

[21] Starkey L. Rawlins P. (2012). Student Teacher Learning During Practicum Experience. Teacher Education Advancement Network Vol 4 (1).

[22] Darling-Hammond L. (2010). Evaluating Teacher Effectiveness. How Teacher Performance Assessments Can Measure and Improve Teaching. Centre for American Progress.

[23] Jeffery J. (2012). Science, Technology, Engineering and mathematics Education: A Primer. CRS Report for Congress.

Citation: Rose Atieno, Mutende. "Influence of Supervision Practices on the Teaching Practice Performance of Bachelor of Education Science Students: A Case of A Public University In Western Kenya." International Journal of Humanities Social Sciences and Education (IJHSSE), vol 4, no. 8, 2017, pp. 51-57. doi:http://dx.doi.org/10.20431/2349-0381.0408006.

Copyright: (ㅇ 2017 Authors. This is an open-access article distributed under the terms of the Creative Commons Attribution License, which permits unrestricted use, distribution, and reproduction in any medium, provided the original author and source are credited. 